\title{
ANALISIS DAYA SAING DOSEN DALAM MENGHADAPI ERA MASYARAKAT EKONOMI ASEAN (Studi Kasus Dosen Fakultas Ekonomi pada PTS di Kota Palembang)
}

\author{
Pandriadi, Asma Mario \\ Fakultas Ekonomi Universitas IBA Palembang \\ pandriada_msi@yahoo.com
}

\begin{abstract}
ABSTRAK
Pandriadi, Asma Mario; Penelitian ini bertujuan untuk menganalisis daya saing dosen menghadapi era MEA, studi kasus di Fakultas Ekonomi di beberapa universitas di Kota Palembang. Daya saing diukur oleh empat indikator yaitu kemampuan bahasa Inggris, kemampuan untuk mendapatkan dana penelitian, kemampuan untuk mendapatkan dana untuk layanan masyarakat dan kemampuan untuk menerbitkan artikel dalam jurnal. Responden dalam penelitian ini adalah 100 dosen yang bekerja di beberapa universitas swasta di Kota palembang. Mereka mengisi kuesioner yang berisi informasi tentang kompetensi mereka dalam empat indikator. Berdasarkan analisis, penelitian ini menyimpulkan bahwa daya saing mayoritas responden rendah, karena dari 100 responden, 94 memiliki daya saing rendah, 4 memiliki daya saing menengah dan nol daya saing tinggi. Peneliti merekomendasikan bahwa untuk meningkatkan daya saing, universitas harus mengadakan pelatihan bahasa Inggris yang berkelanjutan untuk dosen dan juga memberikan dukungan dana kepada dosen untuk melakukan penelitian dan program layanan masyarakat.
\end{abstract}

\begin{abstract}
Pandriadi, Asma Mario; This research aims to analyze the competitiveness of lecturer facing AEC era, a case study in Economic Faculty at some universities in Palembang City. The competitiveness is measured by four indicators namely ability of English, ability to get research funding, ability to get funding for community service and ability to publish articles in journal. Respondent in this research are 100 lecturers who work in some private universities in palembang City. They filled a questionnaire which contents information about their compentencies in four indicators. Based on the analysis, this research concludes that the competitiveness of respondent majority are low, because from 100 respondent, 94 have low competitiveness, 4 have middle competitiveness and zero high competitiveness. The researcher recommend that for increasing competitiveness, the university should hold a sustainable English training for lecturers and also gives funding support to lecturer for doing researchs and community services programs.
\end{abstract}

Key Words: Competitiveness, Lecturer, ASEAN Economic Community

\section{LATAR BELAKANG}

Era liberalisasi ekonomi menjadi sebuah konsekuensi dari perkembangan teknologi dan informasi. Jika sebelumnya sebuah negara dapat melakukan berbagai upaya proteksi untuk melindungi produk barang dan jasa mereka, misalnya dengan kebijakan tarif, kuota ataupun pengenaan pajak impor, maka dalam sebuah era perdagangan bebas upaya proteksi tersebut menjadi tidak mungkin untuk dilakukan. Era ini ditandai dengan semakin cepatnya aliran barang dan jasa antar negara dan semakin berkembangnya inovasi di bidang teknologi informasi, perdagangan, politik dan keuangan.

Pada hakikatnya, era liberalisasi ekonomi dapat dikatakan sebagai sebuah "pisau bermata dua" dimana pada satu sisinya bisa digunakan untuk hal-hal positif namun disisi lain dapat juga menciderai diri sendiri. Analogi ini dapat difahami manakala liberalisasi pada satu sisi sebetulnya adalah sebuah peluang bagi suatu negara untuk mengembangkan produk barang dan jasa dalam negeri mereka, dimana mereka akan mempunyai pasar yang semakin luas dan tidak terbatas namun di sisi lain akan ada ancaman berupa kemudahan produk barang dan jasa luar negeri untuk masuk ke dalam pasar domestik.

Faktanya, persaingan tidak hanya terjadi pada tataran produk barang saja, namun juga terjadi pada sumber daya manusia. Kemudahan tenaga kerja untuk bermigrasi dari satu negara ke negara yang lain tentu saja memberikan dampak positif dan negatif bagi tenaga kerja. Dampak positif dirasakan manakala tenaga kerja domestic mampu berkiprah dan berinteraksi dengan dunia luar sehingga memberikan manfaat positif. Di sisi lain, akan menjadi hal yang negatif jika daya saing tenaga kerja tersebut tidak cukup kuat jika dibandingkan dengan tenaga kerja dari negara lain sehingga akan kalah bersaing dalam mendapatkan peluang. 
Oleh karena itu, kata kunci utamanya adalah daya saing. Berdasarkan data dari World Economic Forum (WEF) tahun 2015, Indonesia menempati urutan 33 dari 140 negara dalam hal daya saing tenaga kerja. Dengan demikian dapat diketahui bahwa peringkat daya saing tenaga kerja Indonesia masih tertinggal jika dibandingkan dengan daya saing tenaga kerja dari beberapa negara tetangga seperti Singapura, Malaysia dan Philipina.

Lebih mengerucut lagi dalam dunia pendidikan, daya saing Indonesia pun masih relatif tertinggal jika dibandingkan dengan beberapa negara tetangga. Misalnya dalam hal ranking perguruan tinggi antara Indonesia dan Malaysia, dimana peringkat dperingkat perguruan tinggi di Malaysia masih jauh lebih baik daripada perguruan tinggi di Indonesia (Kemenristekdikti, 2016)

Jika secara institusi/kelembagaan Indonesia tertinggal dari negara yang lain, maka tidak heran jika di breakdown daya saing sumber daya manusianya (dalam hal ini dosen) juga cukup tertinggal dalam berbagai aspek jika dibandingkan dengan dosen dari negara lain, misalnya dalam hal kemampuan bahasa Inggris, kemampuan mendapatkan dana penelitian dan pengabdian masyarakat dari institusi luar serta kemampuan publikasi ilmiah. Dalam hal publikasi internasional, jumlah publikasi yang dilakukan oleh dosen Indonesia jauh tertinggal jika dibandingkan dengan publikasi internasional yang dilakukan oleh dosen Malaysia dan Thailand.

Maka, dalam lingkup kecil penelitian ini dimaksudkan untuk mengetahui tingkat daya saing dosen Fakultas Ekonomi pada Perguruan Tinggi Swasta (PTS) di Kota Palembang. Pengambilan dosen Fakultas Ekonomi karena seharusnya sebagai dosen di Fakultas Ekonomi mereka lebih mengetahui tentang penerapan Masyarakat Ekonomi ASEAN (MEA) dibandingkan dengan dosen-dosen yang mengajar di fakultas lain. Sehungga dengan menyadari konsekuensi penerapan MEA tersebut maka apakah dosen-dosen di fakultas ekonomi sudah mulai berfikir untuk meningkatkan daya saing mereka baik di tingkat lokal, nasional maupun internasional.

\section{LANDASAN TEORI}

Peraturan Menteri Pendidikan Nasional No.41 Tahun 2007 tentang standar proses, mendefinisikan daya saing sebagai kemampuan untuk menunjukkan hasil yang lebih baik, lebih cepat atau lebih bermakna. Kemampuan yang dimaksud adalah; pertama, kemampuan memperkokoh pangsa pasarnya. Kedua, kemampuan menghubungkan dengan lingkungannya. Ketiga, kemampuan meningkatkan kinerja tanpa henti dan keempat, kemampuan menegakkan posisi yang menguntungkan. Sementara itu, World Economic Forum (WEF) mendefinisikan daya saing sebagai kombinasi dari institusi, kebijakan dan faktor yang menentukan tingkat produktivitas suatu negara. Dimana tingkat produktivitas akan menentukan tingkat kemakmuran yang dapat dicapai oleh suatu perekonomian. Tingkat produktivitas juga menentukan tingkat pengembalian investasi dalam perekonomian yang pada akhirnya menjadi pendorong fundamental dari pertumbuhan ekonomi. Dengan kata lain, negara yang berdaya saing akan cenderung memiliki pertumbuhan ekonomi yang lebih cepat (WEF, 2016).

Daya saing (competitiveness) ditentukan oleh produktivitas suatu negara dalam menggunakan sumberdaya alam, manusia, dan modalnya. Pada dasarnya daya saing diperlukan untuk meningkatkan standar dan kualitas hidup serta untuk meningkatkan eksistensi ekonomi menjadi lebih berorientasi pasar. Lebih lanjut, daya saing adalah untuk meningkatkan produktivitas faktor produksi dan efisiensi secara teknis dalam proses produksi (Robiani, 2004).

Porter (2004) berpendapat bahwa kemakmuran suatu negara sangat dipengaruhi oleh daya saingnya terutama dalam hal sumber daya manusia, modal dan sumber daya alam. Daya saing tersebut dapat terukur dari fundamental mikro ekonomi suatu negara, kepuasan perusahaan dan kualitas dari lingkungan bisnis.

Lebih lanjut, Snowndon dan Stonehouse (2006) berpendapat bahwasannya poin penting dari keunggulan kompetitif suatu negara adalah sebuah paradoks lokasi (location paradox) dimana peningkatan globalisasi dunia akan membuka pasar internasional dan aliran dan pertukaran informasi, ide, sumber daya yang menyebabkan lokasi menjadi hal yang kurang penting, sehingga secara virtual aktivitas ekonomi dapat dilakukan dari berbagai tempat. Sebagai contoh empiris dari studi kasus negaranegara kecil yang dapat mengintegrasikan diri mereka dalam perdagangan global, misalnya Singapura.

Istvan dkk (2016) yang meneliti tentang persaingan perguruan tinggi di Eropa menemukan bahwa jumlah mahasiswa di perguruan tinggi Eropa cenderung mengalami penurunan sehingga mau tidak mau mereka harus meningkatkan daya saing mereka untuk mampu bersaing dengan perguruan tinggi di luar eropa, seperti di Amerika, Asia dan Australia.

Bagaimanapun, keberhasilan pengelolaan pendidikan tinggi merupakan kunci penting untuk mendukung pertumbuhan ekonomi jangka panjang suatu negara (Aghion dkk, 2008). Singkatnya, kualitas tenaga kerja di perguruan tinggi adalah kunci untuk pengembangan, peningkatan dan munculnya inovasi 
dunia (Krenner-Horneffer, 2014) sehingga masing-masing perguruan tinggi perlu membuat dan melaksanakan strategi pengembangan sumber daya manusianya yang mampu memberi ruang untuk meningkatkan kualitas dan daya saing mereka.

Di sisi lain, ASEAN (Association of Southeast Asian Nation) merupakan organisasi politik, ekonomi dan sosial budaya negara-negara Asia Tenggara. ASEAN didirikan oleh Indonesia, Malaysia, Filipina, Singapura dan Thailand pada tanggal 8 Agustus 1967 di Bangkok (Khoman, 1992). Saat ini, jumlah anggota ASEAN menjadi sebanyak 10 negara dengan masuknya Brunei Darussalam, Kamboja, Laos, Myanmar, dan Vietnam. Cita-cita dari ASEAN menjadi kesatuan wilayah ekonomi sudah dirintis sejak 1977 dengan dibentuknya ASEANPreferential Trading Arrangement dan dimulainya ASEAN Free Trade Area pada tahun 1992 (Swajaya, 2014).

Berbagai kerjasama digalang oleh negara-negara anggota ASEAN hingga pada tahun 2003 saat dilakukan pertemuan di Bali disepakati dan dideklarasikan ASEAN Economic Community (AEC) atau disebut Masyarakat Ekonomi ASEAN (MEA). Tujuan dibentuknya MEA adalah untuk menjadikan ASEAN sebuah wilayah yang stabil, sejahtera dan kompetitif dengan perkembangan ekonomi yang merata, kemiskinan yang berkurang, sosio ekonomi yang beragam namun semuanya meningkat secara tandem bersama-sama dalam sebuah komunitas sosio kultural dan politik yang aman (Sudomo, 2017).

Lebih lanjut, MEA yang diterapkan pada tahun 2015 yang lalu memiliki empat pilar, yaitu (1) pasar tunggal dan basis produksi, (2) kawasan ekonomi berdaya saing tinggi, (3) kawasan dengan pembangunan ekonomi yang setara, dan (4) kawasan yang terintegrasi penuh dengan dengan ekonomi global. Dengan adanya MEA tujuan yang ingin dicapai adalah adanya aliran bebas barang, jasa, dan tenaga kerja terlatih (skilled labour) serta aliran investasi yang lebih bebas. (Kementerian Perdagangan RI, 2015). Dengan demikian, tenaga kerja terdidik, salahsatunya adalah dosen menjadi salah satu subyek dalam MEA sehingga tidak dapat dipungkiri bahwa persaingan antar dosen di kawasan Asia Tenggara akan semakin terbuka.

Penelitian yang dilakukan oleh Sudomo (2017) yang meneliti tentang gaung Masyarakat Ekonomi ASEAN di lingkungan profesi sekretaris diperoleh hasil bahwasannya dari 20 asosiasi sekretaris yang diteliti hanya 5 persen yang mempublikasikan topik persiapan menyongsong MEA. Sedikitnya sosialisasi tentang MEA dan sertifikasi profesi menjadi penyebab para praktisi sekretaris belum ingin mengangkat topik MEA. Namun demikian, menurut Sudomo walaupun profesi sekretaris masih belum memiliki tuntutan untuk sertifikasi kompetensi di tingkat ASEAN namun topik MEA harus mulai digaungkan kepada publik, khususnya praktisi sekretaris dan institusi pendidikan.

\section{METODOLOGI}

Peneliti menggunakan metode deskriptif kualitatif dan data primer dimana data di peroleh dengan menyebar kuesioner yang berisi pertanyaan yang relevan dengan pertanyaan penelitian. Responden dalam penelitian ini adalah dosen fakultas ekonomi di beberapa PTS di Kota Palembang, yaitu Universitas Bina Darma, Universitas Muhammadiyah Palembang, Universitas PGRI Palembang, Universitas IBA, Universitas Katolik Musi Charitas dan Universitas Taman Siswa. Berdasarkan data awal, terdapat 175 dosen di enam PTS tersebut sehingga peneliti menggunakan teknik sampling jenuh. Namun demikian, karena penelitian dilakukan saat masa libur kuliah dimana banyak dosen yang tidak datang ke kampus maka kuisioner yang kembali dan dapat diolah hanya berjumlah 100 kuiseoner.

Peubah yang diamati dalam penelitian ini adalah kemampuan Bahasa Inggris, kemampuan mendapatkan dana penelitian, kemampuan mendapatkan dana pengabdian masyarakat dan kemampuan melakukan publiksasi ilmiah. Untuk mengukur peubah ini, maka peneliti telah menetapkan scoring dari yang paling kecil (bernilai 20) sampai yang paling besar (bernilai 100). Misalnya dalam kemampuan Bahasa Inggris skor terbesar diberikan kepada responden yang pernah mengikuti test TOEFL dan atau IELTS Internasional dengan skor yang tinggi (550 ke atas untuk TOEFL dan 6.5 ke atas untuk IELTS). Sedangkan skor terkecil diberikan kepada respondent yang belum pernah mengikuti salah satu atau kedua jenis test tersebut.

Begitu juga dengan kemampuan mendapatkan dana penelitian dan pengabdian masyarakat yang di beri skor berdasarkan sumber pemberi dana, volume dan besarnya dana yang diperoleh. Skor tertinggi diberikan kepada responden yang mendapatkan dana penelitian dari sumber internasional dengan volume lebih dari sekali dalam setahun dan dalam jumlah yang besar. Sedangkan skor terkecil diberikan kepada responden yang belum pernah memperoleh dana penelitian dari pihak manapun.

Untuk publikasi ilmiah, skor di hitung berdasarkan reputasi jurnal tempat memuat artikel, misalnya apakah artikel diterbitkan di jurnal nasional tidak terakreditasi, nasional terakreditasi ataukah di jurnal internasional. Skor tertinggi tentu diberikan kepada responden yang melakukan publikasi di 
jurnal internasional dengan volume lebih dari sekali dalam 1 tahun, sedangkan skor terkecil diberikan kepada responden yang tidak/belum pernah melakukan publikasi ilmiah.

Setelah masing-masing peubah setiap indikator dihitung maka akan dihitung nilai rata-rata daya saing untuk kemudian ditentukan tingkat daya saing masing-masing responden yaitu dengan nilai indikator sebagai berikut:

Tabel 1. Nilai Indikator dan Tingkat Daya Saing

\begin{tabular}{|l|c|}
\hline \multicolumn{1}{|c|}{ Rata-Rata Nilai Indikator } & Tingkat Daya Saing \\
\hline Kurang dari 50 & Rendah \\
\hline $50-79$ & Sedang \\
\hline Lebih dari atau sama dengan 80 & Tinggi \\
\hline
\end{tabular}

Berdasarkan indikator tersebut maka akan dapat ditentukan persentase daya saing dosen berdasarkan tingkat daya saing rendah, sedang dan tinggi.

\section{HASIL PENELITIAN DAN PEMBAHASAN}

\section{Karakteristik Responden}

Mayoritas responden dalam penelitian ini didominasi oleh responden perempuan sebanyak 63 orang (63\%) dan sisanya sebanyak 37 orang (37\%) adalah responden laki-laki. Sedangkan jika dilihat berdasarkan umurnya, responden dari penelitian ini didominasi oleh responden dengan kelompok umur 45 sampai 54 tahun (47\%), diikuti dengan kelompok umur 35 sampai 44 tahun (19\%), umur 25 sampai 34 tahun (18\%), dan di urutan terakhir dengan umur lebih dari 55 tahun (16\%).

Dilihat dari asal universitas, penelitian ini dilakukan di 6 PTS di Kota Palembang, yaitu di Universitas Bina Darma (UBD), Universitas Katolik Musi Charitas (UKMC), Universitas Muhammadiyah Palembang (UMP), Universitas Taman Siswa (Unitas), Universitas PGRI, dan Universitas IBA (UIBA). Berdasarkan asal universitas, distribusi responden dalam penelitian ini dapat dilihat pada tabel berikut:

Tabel 2. Distribusi Responden Menurut Asal Universitas

\begin{tabular}{|c|c|c|}
\hline Universitas & Jumlah & Persen \\
\hline Universitas Bina Darma & 15 & 15 \\
\hline Universitas Katolik Musi Charitas & 15 & 15 \\
\hline Universitas Muhammadiyah Palembang & 20 & 20 \\
\hline Universitas Taman Siswa & 10 & 10 \\
\hline Universitas PGRI & 29 & 29 \\
\hline Universitas IBA & 11 & 11 \\
\hline Jumlah & $\mathbf{1 0 0}$ & $\mathbf{1 0 0}$ \\
\hline
\end{tabular}

Sumber: Data lapangan 2018, diolah.

Jika ditelusuri lebih lanjut berdasarkan program studi, distribusi responden dalam penelitian ini jumlahnya sama antara program studi Akuntansi dan Manajemen yaitu masing-masing sebanyak 50 orang (50\%) dengan tingkat pendidikan mayoritas responden didominasi oleh responden dengan tingkat pendidikan S2 sebanyak 97 orang (97\%) dan S3 sebanyak 3 orang (3\%).

\section{Kemampuan Bahasa Inggris}

Untuk mengetahui kemampuan Bahasa Inggris responden maka peneliti menggunakan kuisioner yang berisi pertanyaan yang menggali kemampuan bahasa inggris responden yang didasarkan pada nilai TOEFL dan IELTS yang sudah menjadi rujukan umum kemampuan Bahasa Inggris seseorang. Pertanyaan dimulai dengan menanyakan apakah responden pernah pengikuti test TOEFL dan atau IELTS, jika pernah mengikuti test tersebut apakah dilaksanakan dalam 2 tahun terakhir, jenis test yang dilakukan sampai pada skor atau nilai test tersebut. Berdasarkan pertanyaan-pertanyaan tersebut maka dapat dirumuskan gambaran kemampuan Bahasa Inggris responden sebagaimana dalam penjelasan berikut. Dari sisi keikutsertaan responden dalam test kemampuan Bahasa Inggris diketahui bahwa 5 dari 100 orang responden belum pernah mengikuti test yang dimaksud. Dari 95 orang yang pernah mengikuti test TOEFL dan IELTS setelah ditelusuri lebih lanjut ternyata 44 orang dari mereka melakukan test tersebut dalam kurun waktu lebih dari 2 tahun terakhir sedangkan 51 orang melaksanakannya dalam kurun waktu dua tahun terakhir. 
Kurun waktu pelaksanaan test cukup menentukan kemampuan Bahasa Inggris seseorang. Test yang dilaksanakan lebih dari 2 tahun terakhir memberikan beberapa implikasi antara lain bahwa sertifikat keikutsertaan berikut nilai/skor di dalamnya tidak diakui. Berbagai institusi baik dunia kerja maupun dunia pendidikan mempersyaratkan masa berlaku test Bahasa Inggris adalah 2 tahun sehingga bagi yang lebih dari 2 tahun tidak diakui lagi dan disarankan untuk kembali mengikuti test. Dalam penelitian ini, responden yang melaksanakan test dalam kurun waktu lebih dari 2 tahun tidak dilakukan analisis yang lebih mendalam karena nilai yang mereka peroleh dianggap tidak valid lagi.

Berdasarkan hasil pengolahan kuesioner terhadap 100 responden dengan mengacu kepada pembobotan sesuai dengan hasil yang diperoleh masing-masing responden dan dengan memperhatikan keikutsertaan responden dalam test Kemampuan Bahasa Inggris, kurun waktu keikutsertaan, jenis test yang diikuti dan skor/nilai yang diperoleh maka dapat diklasifikasikan nilai daya saing responden berdasarkan kemampuan Bahasa Inggrisnya sebagai berikut:

Tabel 3. Nilai Daya Saing Responden Menurut Kemampuan Bahasa Inggris

\begin{tabular}{|c|c|c|c|}
\hline Rata-Rata Nilai & Jumlah & Persen & $\begin{array}{c}\text { Tingkat Daya } \\
\text { Saing }\end{array}$ \\
\hline$<50$ & 76 & 76 & Rendah \\
\hline $50-79$ & 20 & 20 & Sedang \\
\hline$\geq 80$ & 4 & 4 & Tinggi \\
\hline Jumlah & $\mathbf{1 0 0}$ & $\mathbf{1 0 0}$ & \\
\hline
\end{tabular}

Sumber: Data lapangan 2018, diolah.

Dengan demikian dapat diketahui bahwasannya dari sisi kemampuan Bahasa Inggris mayoritas responden dalam penelitian ini memiliki tingkat daya saing yang rendah (sebesar 76 persen) sementara sisanya sebasar 20 persen memiliki daya saing yang sedang dan hanya sebesar 4 persen yang memiliki daya saing tinggi dalam hal kemampuan Bahasa Inggris.

\section{Kemampuan Mendapatkan Dana Penelitian}

Kemampuan mendapatkan dana penelitian menjadi salah satu tolok ukur dalam menilai daya saing dosen. Sebagaimana diketahui bahwasannya tersedia cukup banyak dana-dana penelitian baik dari internal perguruan tinggi maupun dari institusi pemerintah dan swasta baik dari dalam maupun luar negeri. Dana-dana hibah penelitian tersebut mayoritas bersifat kompetitif sehingga yang bisa mendapatkan dana penelitian tersebut dianggap mempunyai daya kompetisi. Semakin tinggi tingkatan pemberi dana maka dapat dikatakan bahwa akan semakin tinggi kemampuan daya saing seorang dosen. Dari hasil penelitian dapat diketahui bahwa mayoritas (78 persen) pernah mendapatkan dana penelitian. Hal ini tentu cukup baik, namun demikian setelah ditelusuri lebih lanjut ternyata dari 78 orang responden yang pernah mendapatkan dana penelitian terdapat 35 responden yang mendapatkannya dalam kurun waktu lebih dari 2 tahun. Hal ini dapat dimaknai bahwa mereka sudah cukup lama tidak mendapatkan dana penelitian padahal berbagai pihak menyediakan dana hibah penelitian setiap tahunnya. Dari 43 orang responden yang mendapatkan dana dalam kurun waktu 2 tahun terakhir jika ditelusuri lebih lanjut sumber dananya dapat diketahui bahwa 41,86 persen berasal dari internal perguruan tinggi, 51,16 persen dari institusi pemerintah dan swasta dalam negeri dan 6,98 persen diperoleh dari institusi pemerintah dan swasta luar negeri.

Berdasarkan hasil pengolahan kuesioner terhadap 100 responden dengan mengacu kepada pembobotan sesuai dengan hasil yang diperoleh masing-masing responden dan dengan memperhatikan pengalaman responden dalam mendapatkan dana penelitian, kurun waktu memperoleh dana, sumber pemberi dana, volume memperoleh dana dan skor/nilai yang diperoleh maka dapat diklasifikasikan nilai daya saing responden berdasarkan kemampuan mendapatkan dana penelitian adalah sebagai berikut:

Tabel 4. Nilai Daya Saing Responden Menurut Kemampuan Mendapatkan Dana Penelitian

\begin{tabular}{|c|c|c|c|}
\hline Rata-Rata Nilai & Jumlah & Persen & $\begin{array}{c}\text { Tingkat Daya } \\
\text { Saing }\end{array}$ \\
\hline$<50$ & 82 & 82,00 & Rendah \\
\hline $50-79$ & 15 & 15,00 & Sedang \\
\hline$\geq 80$ & 3 & 3,00 & Tinggi \\
\hline Jumlah & $\mathbf{1 0 0}$ & $\mathbf{1 0 0 , 0 0}$ & \\
\hline
\end{tabular}

Sumber: Data lapangan 2018, diolah. 
Dengan demikian dapat diketahui bahwasannya dari sisi kemampuan mendapatkan dana penelitian mayoritas responden dalam penelitian ini memiliki tingkat daya saing yang rendah (sebesar 82 persen) sementara sisanya sebesar 15 persen memiliki daya saing yang sedang dan hanya sebesar 3 persen yang memiliki daya saing tinggi dalam hal kemampuan mendapatkan dana penelitian.

\section{Kemampuan Mendapatkan Dana Pengabdian Masyarakat}

Berdasarkan hasil penelitian, dari 100 responden ternyata terdapat 49 responden (atau 49 persen) yang belum pernah mendapatkan dana kegiatan pengabdian kepada masyarakat. Hal ini menunjukkan masih cukup banyak dosen yang belum pernah mendapatkan dana kegiatan pengabdian kepada masyarakat. Apalagi, setelah ditelusuri lebih lanjut ternyata dari 51 orang responden yang pernah mendapatkan dana pengabdian masyarakat terdapat 21 responden yang mendapatkannya dalam kurun waktu lebih dari 2 tahun. Hal ini dapat dimaknai bahwa mereka sudah cukup lama tidak mendapatkan dana pengabdian masyarakat padahal berbagai pihak menyediakan dana hibah pengabdian masyarakat setiap tahunnya.

Berdasarkan hasil pengolahan kuesioner terhadap 100 responden dengan mengacu kepada pembobotan sesuai dengan hasil yang diperoleh masing-masing responden dan dengan memperhatikan pengalaman responden dalam mendapatkan dana pengabdian masyarakat, kurun waktu memperoleh dana, sumber pemberi dana, volume memperoleh dana dan skor/nilai yang diperoleh maka dapat diklasifikasikan nilai daya saing responden berdasarkan kemampuan mendapatkan dana pengabdian masyarakat adalah sebagai berikut:

Tabel 5. Nilai Daya Saing Responden Menurut Kemampuan Mendapatkan Dana Pengabdian Masyarakat

\begin{tabular}{|c|c|c|c|}
\hline Rata-Rata Nilai & Jumlah & Persen & $\begin{array}{c}\text { Tingkat Daya } \\
\text { Saing }\end{array}$ \\
\hline$<50$ & 95 & 95,00 & Rendah \\
\hline $50-79$ & 4 & 4,00 & Sedang \\
\hline$\geq 80$ & 1 & 1,00 & Tinggi \\
\hline Jumlah & $\mathbf{1 0 0}$ & $\mathbf{1 0 0 , 0 0}$ & \\
\hline
\end{tabular}

Sumber: Data lapangan 2018, diolah.

Dengan demikian dapat diketahui bahwasannya dari sisi kemampuan mendapatkan dana pengabdian masyarakat mayoritas responden dalam penelitian ini memiliki tingkat daya saing yang rendah (sebesar 95 persen) sementara sisanya sebesar 4 persen memiliki daya saing yang sedang dan hanya sebesar 1 persen yang memiliki daya saing tinggi dalam hal kemampuan mendapatkan dana pengabdian masyarakat.

\section{Kemampuan Melakukan Publikasi Ilmiah}

Kemampuan melakukan publikasi ilmiah juga menjadi salah satu tolok ukur dalam menilai daya saing dosen. Kegiatan ini merupakan salah satu kewajiban dosen untuk menuangkan hasil-hasil penelitian mereka ke dalam jurnal ilmiah. Seharusnya, paling tidak seorang dosen melakukan publikasi ilmiah sebanyak dua kali dalam satu tahun. Saat ini tersedia cukup banyak media untuk menampung tulisan ilmiah dosen mulai dari jurnal yang dimiliki oleh program studi, fakultas atau universitas dimana dosen tersebut mengajar maupun di tempat lain mulai dari jurnal yang tidak terakreditasi, terakreditasi sampai dengan jurnal internasional yang terindeks.

Dari hasil penelitian dapat diketahui bahwa persentase responden yang pernah melakukan publikasi ilmiah sebanyak 96 persen, sisanya sebanyak 4 persen belum pernah melakukan publikasi ilmiah. Sayangnya, dari jumlah 96 persen responden yang pernah melakukan publikasi ilmiah ternyata publikasi tersebut hanya 74 responden yang melakukannya dalam kurun waktu 2 tahun terakhir, sedangkan sisanya sebanyak 22 responden melakukannya lebih dari 2 tahun yang lalu. Dari 74 orang responden yang melakukan publikasi ilmiah dalam kurun waktu 2 tahun terakhir jika ditelusuri lebih lanjut tempat publikasinya diketahui bahwa 66,22 persen di jurnal nasional tidak terakreditasi, 28,38 persen di jurnal nasional terakreditasi dan hanya 5,40 persen di jurnal internasional.

Berdasarkan hasil pengolahan kuesioner terhadap 100 responden dengan mengacu kepada pembobotan sesuai dengan hasil yang diperoleh masing-masing responden dan dengan memperhatikan pengalaman responden dalam melakukan publikasi ilmiah, kurun waktu melakukan publikasi, media publikasi, volume publikasi dan skor/nilai yang diperoleh maka dapat diklasifikasikan nilai daya saing responden berdasarkan kemampuan melakukan publikasi ilmiah adalah sebagai berikut: 
Tabel 6. Nilai Daya Saing Responden Menurut Kemampuan Melakukan Publikasi Ilmiah

\begin{tabular}{|c|c|c|c|}
\hline Rata-Rata Nilai & Jumlah & Persen & $\begin{array}{c}\text { Tingkat Daya } \\
\text { Saing }\end{array}$ \\
\hline$<50$ & 86 & 86,00 & Rendah \\
\hline $50-79$ & 9 & 9,00 & Sedang \\
\hline$\geq 80$ & 5 & 5,00 & Tinggi \\
\hline Jumlah & $\mathbf{1 0 0}$ & $\mathbf{1 0 0 , 0 0}$ & \\
\hline
\end{tabular}

Sumber: Data lapangan 2018, diolah.

Dengan demikian dapat diketahui bahwasannya dari sisi kemampuan melakukan publikasi ilmiah mayoritas responden dalam penelitian ini memiliki tingkat daya saing yang rendah (sebesar 95 persen) sementara sisanya sebesar 9 persen memiliki daya saing yang sedang dan hanya sebesar 5 persen yang memiliki daya saing tinggi dalam hal kemampuan melakukan publikasi ilmiah.

\section{Analisis Nilai Daya Saing Menurut Empat Indikator}

Berdasarkan hasil perhitungan keseluruhan maka dapat dirangkum rata-rata nilai daya saing dosen berdasarkan empat indikator, yaitu kemampuan Bahasa Inggris, kemampuan mendapatkan dana penelitian, kemampuan mendapatkan dana pengabdian masyarakat dan kemampuan melakukan publikasi ilmiah secara serentak. Data diperoleh dengan menjumlahkan nilai setiap indikator yang diperoleh setiap responden kemudian dibagi dengan 4 (karena jumlah indikatornya ada 4) dengan hasil sebagai berikut:

Tabel 7. Nilai Daya Saing Responden Menurut Empat Indikator

\begin{tabular}{|c|c|c|c|}
\hline Rata-Rata Nilai & Jumlah & Persen & $\begin{array}{c}\text { Tingkat Daya } \\
\text { Saing }\end{array}$ \\
\hline$<50$ & 94 & 94,00 & Rendah \\
\hline $50-79$ & 6 & 6,00 & Sedang \\
\hline$\geq 80$ & 0 & 0,00 & Tinggi \\
\hline Jumlah & $\mathbf{1 0 0}$ & $\mathbf{1 0 0 , 0 0}$ & \\
\hline
\end{tabular}

Sumber: Data lapangan 2018, diolah.

Dari tabel di atas ternyata dari 100 orang responden ternyata tidak ada yang masuk kategori daya saing tinggi, sedangkan yang masuk kategori daya saing sedang hanya 6 persen, sisanya sebanyak 94 persen masuk kategori berdaya saing rendah. Pada bagian sebelumnya saat melihat daya saing responden per indikator ditemui sejumlah responden yang memiliki daya saing tinggi, namun ternyata daya saing tinggi tersebut hanya diperolehnya pada indikator tersebut sedangkan untuk indikator yang lain nilai daya saingnya rendah, sehingga saat di hitung total 4 indikator nilai daya saingnya tidak begitu tinggi.

\section{SARAN}

Dari hasil pembahasan diperoleh beberapa kesimpulan bahwa berdasarkan analisis daya saing dosen untuk setiap indikator yaitu kemampuan Bahasa Inggris, kemampuan mendapatkan dana penelitian, kemampuan mendapatkan dana pengabdian masyarakat dan kemampuan melakukan publikasi ilmiah dapat diketahui bahwasannya secara umum daya saing dosen mayoritas masuk klasisikasi berdaya saing rendah, meskipun terdapat beberapa dosen yang memiliki daya saing tinggi di beberapa indikator. Namun setelah menghitung daya saing secara bersama-sama ternyata diperoleh hasil dimana daya saing dosen sebagian besar ( 94 persen) memiliki daya saing rendah, 6 persen memiliki daya saing sedang dan tidak ada satu pun yang memiliki daya saing yang tinggi.

Untuk itu dalam penelitian ini peneliti memberikan saran, dimana agar daya saing dosen meningkat dan mampu bersaing di tingkat internasional para dosen perlu dibekali dengan kemampuan Bahasa Inggris. Hal ini penting dilakukan mengingat untuk memperoleh dana dari luar negeri baik itu dana penelitian maupun dana pengabdian masyarakat serta untuk melakukan publikasi internasional memerlukan kemampuan Bahasa Inggris yang baik. Upaya yang dilakukan adalah dengan mengadakan pelatihan Bahasa Inggris secara rutin dan sistematis kepada dosen serta membentuk forum-forum diskusi berbahasa Inggris di dalam kampus yang dimulai dari tingkat program studi, fakultas sampai dengan universitas. Selain itu, perguruan tinggi seharusnya memberikan dukungan pendanaan internal secara rutin setiap tahun kepada dosen untuk melakukan kegiatan penelitian dan pengabdian masyarakat serta untuk melakukan publikasi atas kegiatan-kegiatan tersebut. Dukungan dana ini sangat diperlukan 
untuk merangsang minat dosen melakukan kegiatan penelitian dan pengabdian masyarakat yang berujung pada publikasi ilmiah atas kegiatan yang telah mereka lakukan.

\section{DAFTAR PUSTAKA}

Aghion, P. (2008). Higher aspirations: an agendafor reforming European Universities. Bruegel Blueprint 5, p. 59

Istvan, Labas. Eva, D. Orsolya, N.T. (2016). Competitiveness - Higher Education, Studia Universitatis "Vasile Goldis" Arad. Economics Series Vol 26 Issue 1/2016, ISSN 1584-2339, p. 11-25.

Kemenristekdikti (2016). Daftar Top 500 Perguruan Tinggi Indonesia.

Kementerian Perdagangan Republik Indonesia. (2015). Peluang dan Tantangan Indonesia di Pasar Bebas ASEAN, Warta Ekspor, Januari 2015.

Khoman, T. (1992). ASEAN Conception and Evolution. Diunduh dari www.asean.org.

Kurniawan, G. (2010). Analisis Faktor-Faktor yang Mempengaruhi Produktivitas Tenaga Kerja pada PT Kalimantan Steel Pontianak. Jurnal Ekonomi. Vol. No 12. Hal.41-58

Porter, M.E. (2004). Building the Microeconomic Foundationsof Prosperity: Findings from the Business Competitiveness Index, palgrave macmillan, World Economic Forum: Newyork, p: 19-50

Robiani, Bernadette (2004). The Competitiveness of South Sumatra Industrial Sector, Makalah disampaikan pada Seminar Antar Bangsa, Bengkulu.

Rohmah,N. Huda, M. Kusmintardjo. Strategi Peningkatan Kemampuan Dosen dalam Penulisan Karya Ilmiah (Studi Multi kasus pada UNISDA dan STAIDRA di Kabupaten Lamongan), Jurnal Pendidikan: Teori, Penelitian dan Pengambangan Vol 1 No.7, p. 1312-1322.

Scimagojr (2016). Daftar Publikasi Internasional.

Snowdon,B and Stonehouse, G. (2006). Competitiveness in a globalised world: Michael Porter on the microeconomic foundations of the competitiveness of nations, regions, and firms. Journal of International Business Studies 2006.37, p. 163-175

Subekti, N.B. (2015). Rangking Publikasi Ilmiah Internasional Indonesia, diterbitkan di Koran Sindo, 13 April 2015.

Sudomo, Asmara. (2017). Gaung Masyarakat Ekonomi ASEAN (MEA) di Lingkungan Profesi Sekretaris.

Sunar, (2012). Pengaruh Faktor Biografis (Usia, Masa Kerja dan Gender) Terhadap Produktivitas Karyawan. Forum Ilmiah Vol.9 No. 1.

Swajaya, N. (2014). Indonesia Must Get Ready Nowfor the AEC. Strategic review, April-June Vol 4 no.2, p. 1827.

World Economic Forum (2015), Peringkat Daya Saing Tenaga Kerja 